\title{
胆囊癌の占居部位および進展様式からみた外科治療
}

\author{
金沢大学第 1 外科 \\ 川浦 幸光 森 善裕 中島 久幸 服部 和伸 \\ 九沢豊魚津幸蔵山田哲司岩喬

\section{SURGICAL MANAGEMENT FOR CARCINOMA OF THE GALLBLADDER WITH SPECIAL REFERENCE TO ITS LOCALIZATION AND MODES OF SPREAD}

\section{Yukimitsu KAWAURA, Yoshihiro MORI, Hisayuki NAKAJIMA \\ Kazunobu HATTORI, Yutaka KUZAWA, Kohzo UOZU \\ Tetsuji YAMADA and Takashi IWA \\ Department of Surgery (I), Kanazawa University School of Medicine}

\begin{abstract}
過去10年間に経験した切除不能例を含む胆震癌35例の占居部位を次のごとく分けた．底部を中心と する $(\mathrm{Gf})$ 群, 体部 $(\mathrm{Gb})$ 群, 頸部 $(\mathrm{Gn})$ 群, 全体群, 腹腔側群, 肝床群とした. 予後因子との関係 は, 1) Gn 群では門脈浸潤率 (7/11), (12)番リンパ節陽性率 (9/11) が高かった。2) 肝転移は全体群, Gf 群で高率に認められた。 3) 十二指腸浸潤 ( D因子) は腹腔側群, 全体群で高率であった。結果を基 に術式として以下を考慮している，1）Gf 群，Gb 群の肝床群では肝床切除, 腹腔側群では辇頭後部り ンバ節郭清を考虑, 2) 肝床群で肝内直接浸潤 (Hinf) 例のうち Hinf $_{1-2}$ では肝床切除を, Hinf $_{1-3}$ 十胆 管浸潤例では肝切除を併施. 腹腔側群で D因子 (+) 例で脇十二指腸切除を併施. 3) $\mathrm{Gn}$ 群では門脈 合併切除を考虑すべきである。
\end{abstract}

卖引用語：胆襄癌の占居部位, 胆裹癌の進展様式, 胆衰癌の占居部位からみた手術術式の選択

$$
\text { はじめに }
$$

胆囊は粘膜筋板を欠き, 胆囊癌の発育は他の消化器 系癌に比べて速やかである.リンパ流も2 方向性のも のであり ${ }^{1)}$, 占居部位により進展様式を考虑しつつ術 式を決定すべきである。

\section{対象}

過去10年間に経験した切除不能例を含む胆囊癌 35 例 を対象とした，以下に用いる名称は胆道癌取扱い規 約2门に従った。

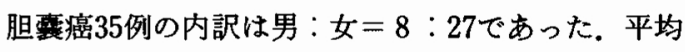
年龄は男65歳, 女68歳であった。

胆石保有は21例（60\%）で女性に多かった。 初発症状は胆石様発作 $80 \%$ ，呕気 $15 \%$ ，発熱 $13 \%$ で あった. stage 分類では stage I が 4 例， II, 5 例，III,

$<1986$ 年 4 月 9 日受理 $>$ 別刷請求先：川浦 幸光 T920 金沢市宝町13-1 金沢大学医学部第 1 外科
6 例, IV, 20例であった（表 1 ).

切除可能であったのは 8 例のみであり，27例は切除 不能であった，その内 2 例は減黄術後に手術を予定し たが他疾患を合併したため減黄術のみ施行可能であっ た.

占居部位を取扱い規約に従って次のように分類し た. 胆襄底部に癌腫が存在する (Gf) 群, この群には 体部にかかる例 $(\mathrm{Gfb})$ も含めた。体部に存在する $(\mathrm{Gb})$ 群, この群には底部 (Gbf), 頸部 (Gbm) にかかる例

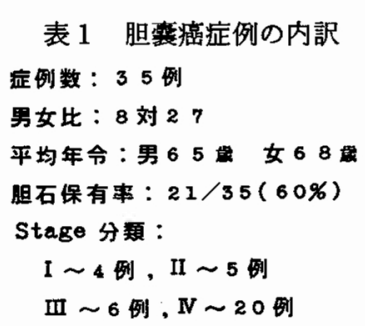


図 1 占居部位の分類

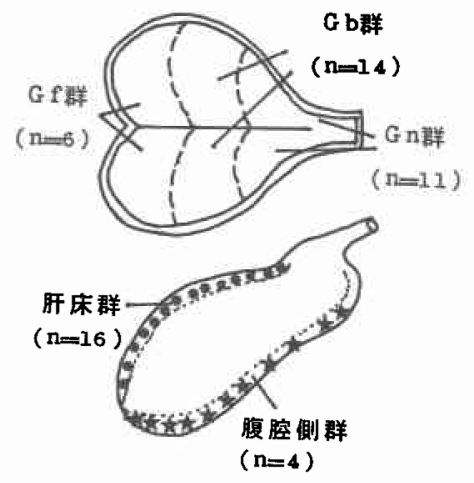

も含めた、頸部に存在する ( $\mathrm{Gn}$ 群), これには体部 (Gmb) にかかる例も含めた。邨よび全体群に分けた。 症例数は Gf 群 6 例, Gb 群14例, Gn 群11例, 全体群 4 例であった。ささらに腹腔側面から発生したと思われる 例 (腹腔側群) と肝床面から発生したと思われる例（肝 床群)に分けた。 Gn 群, 全体群では腹腔側群, 肝床群 の区分ができないため除外した。したがって症例数は 腹腔側群 4 例，肝床群16例であった（図 1 ）.

占居部位の判定は摘出標本では明らかであるが，切 除不能例では開腹所見と各種検査所見をるって判断し た。

\section{成 績}

1）占居部位と肝内直接浸潤（Hinf）

開腹により確認した Hinf 陽性は28例であった，Gf 群で 4 例, $\mathrm{Gb}$ 群で10例, $\mathrm{Gn}$ 群で 8 例, 全体群で 4 例 であった。全体群で $100 \%$ と陽性率が高かったが有意差 とはいえなかった，腹腔側群では陽性例がなく，肝床 群では14例が陽性であった（表 2）。

2）占居部位と門脈浸潤（Vp 因子）

門脈本幹への浸潤は12例であった。 Gf 群では浸潤例 なく, Gb 群で 3 例, $\mathrm{Gn}$ 群で 7 例, 全体群で 2 例であっ た。腹腔側群では浸潤を認めた例はなく，肝床群では 3 例に認められた（表 3 )。

3）占居部位とリンパ節転移

リンパ節転移の検討は切除例 8 例では明らかにする ことができたが，切除不能例では開腹所見にたよらざ るをえなかった，開脈時に可能な限りリンパ節腫大の 検索を行った。

リンパ節転移は肝十二指腸間膜内リンパ節（12)番リ ンパ節), 荤頭後部リンパ節 (13)番リンパ節), 総肝動 脈幹リンパ節(8)番リンパ節)，その他のリンパ節に分
表 2 占居部位と肝内直接浸潤（Hinf）

\begin{tabular}{lll} 
群 & Hinf 謁性数 $(n=28)$ \\
\hline $\mathrm{Gf}$ & $4 / 6$ & $(66.6 \%)$ \\
$\mathrm{Gb}$ & $10 / 14$ & $(71.4 \%)$ \\
$\mathrm{Gn}$ & $8 / 11$ & $(72.7 \%)$ \\
全体 & $4 / 4 \quad(100 \%)$ \\
\hline 腹腔側 & $0 / 4 \quad(0 \%)$ \\
栞 床 $14 / 16(87.5 \%)$ \\
\hline
\end{tabular}

表 3 占居部位と門脈漫潤 (Vp因子)

\begin{tabular}{lll} 
群 & 門脤浸閏数 $(\mathrm{n}=12)$ \\
\hline $\mathrm{Gf}$ & $0 / 6$ & $(0 \%)$ \\
$\mathrm{Gb}$ & $3 / 14$ & $(21.4 \%)$ \\
$\mathrm{Gn}$ & $7 / 11$ & $(63.6 \%)$ \\
全体 & $2 / 4 \quad(50.0 \%)$ \\
\hline 腹䐋側 & $0 / 4$ & $(0 \%)$ \\
肝 床 & $3 / 16$ & $(18.8 \%)$ \\
\hline
\end{tabular}

表 4 占居部位からみたリンパ節転移

\begin{tabular}{|c|c|c|c|c|c|}
\hline \multirow[t]{2}{*}{ 群 } & \multirow[t]{2}{*}{ 転移例数 } & \multicolumn{3}{|c|}{ 転移リンパ節の内訳 } & \multirow[b]{2}{*}{ その他 } \\
\hline & & & (1) & (B) & \\
\hline Gf & $1 / 6$ & 1 & 1 & 0 & 0 \\
\hline $\mathrm{Gb}$ & $7 / 14$ & 4 & 1 & 1 & 2 \\
\hline Gn & $10 / 11$ & 9 & 0 & 1 & 2 \\
\hline 全体 & $4 / 4$ & 3 & 0 & 1 & 3 \\
\hline 腹腔側 & $2 / 4$ & 2 & 1 & 0 & 1 \\
\hline 肝床 & $6 / 16$ & 3 & 1 & 0 & 1 \\
\hline
\end{tabular}

けた、 Gf 群では, (12)および13)に転移を認めた. Gb 群で は(12)に 4 例, (13) 1 例, (8)に 1 例, その他に 2 例転移 を認めた. Gn 群では12)に 9 例の転移を見，他群に比べ て高率であった，全体群では(12)のみならずその他のリ ンパ節にも転移を認めた，腹腔側群では 4 例中 2 例に (12)への転移を認めた。肝床群では(12)に 3 例の転移を認 めた. Gf 群, Gb 群, Gn 群, 全体群を通じてのリンパ 節転移は(12)番 $17 / 35$, (13)番 $2 / 35$, (8)番3/35, その他 $7 / 35$ であった（表 4 )。

4) 占居部位と肝転移（H因子）

肝転移を認めたのは12例（36\%）であった，Gf 群で は2/6, Gb 群では4/14, Gn 群で2/11，全体群で4/4で

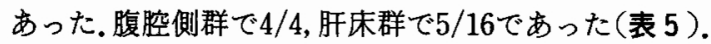

5）占居部位と十二指腸浸潤（D因子）

$\mathrm{D}$ 因子陽性例は 8 例であった。 Gf 群で $2 / 6, \mathrm{~Gb}$ 群で 2/14，Gn 群で2/11，全体群で2/4であった．腹腔側群 では2/4, 肝床群では認めなかった（表 6 ）。

6) 占居部位と胆管漫潤（B因子）

Gn 群で総胆管に直接浸潤したものは 2 例，左およ び右肝管に浸潤したものが 1 例むった。 (12)番, (13)番リ 
表 5 占居部位と肝転移（H因子）

\begin{tabular}{lll} 
群 & \multicolumn{3}{c}{ 肝枟移症例数 $(n=12)$} \\
\hline $\mathrm{Gf}$ & $2 / 6$ & $(33.3 \%)$ \\
$\mathrm{Gb}$ & $4 / 14$ & $(28.6 \%)$ \\
$\mathrm{Gn}$ & $2 / 11$ & $(18.2 \%)$ \\
全体 & $4 / 4$ & $(100 \%)$ \\
\hline 腊䐋侧 & $1 / 4$ & $(25.0 \%)$ \\
肝 床 & $5 / 16$ & $(31.3 \%)$ \\
\hline
\end{tabular}

表 6 占居部位と十二指腸浸潤（D因子）

\begin{tabular}{|c|c|}
\hline 群 & 十二指的㵊相例数 $(\mathrm{n}=$ \\
\hline$\overline{G f}$ & $2 / 6 \quad(33.3 \%)$ \\
\hline $\mathrm{Gb}$ & $2 / 14(14.3 \%)$ \\
\hline $\mathrm{Gn}$ & $2 / 11(18.2 \%)$ \\
\hline 全体 & $(50.0 \%)$ \\
\hline 腈腔即 & $(100 \%)$ \\
\hline 肝 床 & $0 / 16(0 \%)$ \\
\hline
\end{tabular}

表 7 複合因子保有例

\begin{tabular}{|c|c|c|c|c|c|c|c|c|c|}
\hline 群 & HinftN & $\mathrm{Hinf}+\mathrm{H}$ & $\operatorname{Hinf}+D$ & $\mathrm{Vp+H}$ & $N+D$ & $H+D$ & 3西子保有 & 4因子保有 & 5 西子保年 \\
\hline G $f$ & 0 & 0 & 0 & 0 & 0 & 0 & 0 & 0 & 0 \\
\hline Gb & 2 & 1 & 0 & 0 & 0 & 0 & 2注2) & 0 & 0 \\
\hline $\mathrm{Gn}$ & 2 & 1 & 0 & 1 & 0 & 0 & 0 & 工注3) & o \\
\hline 全体 & 0 & 0 & 0 & 0 & 0 & 0 & 0 & 2注() & I注 5) \\
\hline 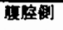 & 0 & 0 & 0 & 0 & I & 1 & 0 & 0 & 0 \\
\hline 剭床 & 2 & 1 & 0 & 1 & 0 & 0 & $2^{\text {注6) }}$ & 0 & 0 \\
\hline
\end{tabular}

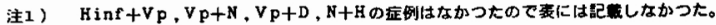
注2) $\mathrm{Hinf}+\mathrm{V}_{\mathrm{p}}+\mathrm{N}$ 加 1 列, $\mathrm{Hinf}+\mathrm{Vp}+\mathrm{H}$ 加工例

注3) $\mathrm{Hinf}+\mathrm{N}+\mathrm{V} \mathrm{p}+\mathrm{H}$

注4) $\mathrm{Hinf}+\mathrm{Vp}+\mathrm{N}+\mathrm{H}$ 加例, $\mathrm{Hinf}+\mathrm{V} p+\mathrm{N}+\mathrm{D}$ 工列

注5) $\mathrm{Hinf}+\mathrm{Vp}+\mathrm{N}+\mathrm{H}+\mathrm{D}$

注6) $\mathrm{Hinf}+\mathrm{Vp}+\mathrm{H}$ ts 2 侧

ンパ節を介して肝十二指腸靸帯に浸潤が及び，その結 果として胆管を巻さ込んだと思われる例が24例あっ た.

7）複合因子保有例

深達度mの 3 例と pm 1 例を除く 31 例について複合 因子を検討した。複合因子の組合せと症例数は表 7 に 一括した，Gf 群では複合因子例はなく，Gb 群では $\mathrm{Hinf}+\mathrm{N}$ が 2 例, $\mathrm{Hinf}+\mathrm{H}$ が 1 例, Hinf $+\mathrm{Vp}+\mathrm{N} 1$ 例, $\mathrm{Hinf}+\mathrm{Vp}+\mathrm{H} 1$ 例であった. Gn 群では Hinf $+\mathrm{N}$ 2 例, Hinf $+\mathrm{H} 1$ 例, $\mathrm{Vp}+\mathrm{H} 1$ 例, Hinf $+\mathrm{N}+\mathrm{Vp}+$ $\mathrm{H} 1$ 例であった. 全体群では Hinf $+\mathrm{Vp}+\mathrm{N}+\mathrm{H} 1$ 例， $\mathrm{Hinf}+\mathrm{Vp}+\mathrm{N}+\mathrm{D} \quad 1$ 例, $\mathrm{Hinf}+\mathrm{Vp}+\mathrm{N}+\mathrm{H}+\mathrm{D} \quad 1$ 例 であった. 腹腔側群では $\mathrm{N}+\mathrm{D} 1$ 例, $\mathrm{H}+\mathrm{D} 1$ 例, 肝 床群では $\mathrm{Hinf}+\mathrm{N}$ が 2 例, $\mathrm{Hinf}+\mathrm{H} 1$ 例, $\mathrm{Vp}+\mathrm{H} 1$ 例， Hinf $+\mathrm{Vp}+\mathrm{H} 2$ 例であった。

9) 術式と予後

単純胆摘 3 例, 胆管 + 肝床切除 2 例, 胆摘十胆管切
除 1 例，拡大肝右葉 (右三区域切除) +荤頭十二指腸切 除術 1 例, 胆摘十肝床切除十膵頭十二指腸切除術 1 例, 减黄術18例，肝動脈内特続動注 5 例であった。

単純胆摘は 1 例はmの早期癌に対してなされた。 2 '例は商齢者 poor risk 例になされ，2 年，1年 2 力月生 存した，胆摘十肝床切除の 1 例は 3 年経過中， 1 例は 1 年 6 カ月経過中である. 胆摘十胆管切除の 1 例は 1 年 8 力月生存中である. 右三区域切除十莁頭十二指腸 切除術の 1 例は $\mathrm{Hinf}_{3}+\mathrm{B}_{3}+\mathrm{H}_{2}+\mathrm{D}$ に対しなされた もので術後 1 カ月で肝不全にて死亡した。胆摘十肝床 切除十膵頭十二指腸切除術の 1 例は $\mathrm{Hinf}_{3}+\mathrm{B}_{3}+\mathrm{D}$ に なされたるので 1 週間目に肝腎症候群で死亡した。

減黄術の最長生存は16力月で平均生存期間は8.6力 月であった.肝動注例の平均生存期間は5.2力月であっ た.

\section{考察}

胆襄癌の発育様式を検討すると占居部位によって漫 潤の様子が異っているのがわかる。

$\mathrm{Gf}$ 群, $\mathrm{Gb}$ 群, $\mathrm{Gn}$ 群, 全体群を比較すると肝内直接 浸潤（Hinf）においては各群間に差は認められなかっ た. 肝床群では Hinf が, 腹腔側群では当然 D因子が問 題となる。Gn 群では胆管への浸潤が多いと予想した が, 直接浸潤はむしろ少く、リンパ節を介しての浸潤 があった.さらに門脈本幹への浸潤が $63.6 \%$ に認めら れた。したがって Gn 群では門脈合併切除を考慮しな いと切除が困難となると思われる。

リンパ節転移に関しては切除例が 8 例と少く，その 他の例は開腹所見での判断であるため不十分な検討で あったが，腹腔側群では切除例の 1 例に(13)番リンパ節 転移牡よび 2 例に(12)番リンパ節転移を認めた。肝床群 では肝床切除を十分に行らことを考慮すべきである.

胆囊癌の他臓器への直接浸潤も多く, Fahim "1) は腹 壁浸潤が多いと述べているが持永ら゙は十二指腸漫潤 が最も多かったと述べている，われわれの検討では腹 壁漫潤例は 2 例に認めたのみであり，十二指腸浸潤が 多かった.

(13)番リンパ節転移を有する例では例え十二指腸への 直接浸潤がなくても膵十二指腸切除を併施すべきであ ると Pack ら ${ }^{4)}$ は述べている，高崎ら ${ }^{5)} 5$ 例に拡大右 葉十荤頭十二指腸切除を試みたが 1 年以上生存例は 1 例のみであった。われわれの 1 例る 1 カ月生存したの みであり，本法が妥当な術式かどらか再考すべき時期 である、角田 ${ }^{6)} \mathrm{pm}$ を越克た例では拡大術式をとっ ても予後につながらなかったと述べている. 
予後決定因子をもつ例では, 佐藤》゙は Hinf 陽性例の 生存期間はすべて 3 年以内であったと述べている. B 因子保有例は高田 ${ }^{8)}$ によると $18 / 39$ に認められ，1 年以 上生存例は 3 例のみであったと述べている。

胆囊癌では根治術のできる症例は極端に少く，姑息 的手術にゆだねられている，減黄術は延命を計る方法 として最もすぐれている。われわれは内瘦術としては Soupault 法9)を原則としており，中权胆管での吻合が

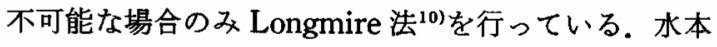
ら ${ }^{111}$ はチューブによる方法を推奨している，B因子 の強い例では腫煌貫通法"2)試みている。

\section{結 語}

過去10年間に経験した胆囊癌36例を検討した。占居 部位を $\mathrm{Gf}, \mathrm{Gb}, \mathrm{Gn}$, 全体, 腹腔側, 肝床に分け，予後 因子の検討を行って手術術式について言及した。占居 部位と予後因子との関係では, 1) $\mathrm{Gn}$ 群で $\mathrm{Vp}$, (12)番リ ンパ節陽性率が高かった，2）H因子は Gf 群, 全体群 で高率であった，3）D因子は腹腔側群で高率であっ た.したがって手術術式として次のような方針で望ん でいる. 1) Gf 群, Gb 群の肝床群では肝床切除, 腹腔 側群では(13)番リンパ節郭法を考慮する，2) $\operatorname{Hinf}_{1-2}$ の 肝床群では肝床切除でよいが, $\operatorname{Hinf}_{1-3}$ 十胆管浸潤例で は肝切除を考慮する。腹腔側群で D (†) 例では荤十 二指腸切除を考学る．3） Gn 群では門脈合併切除を考 慮する。

\section{文献}

1) Fahim RB, McDonald JR, Richards JC et al:
Carcinoma of the gallbladder: A study of its modes of spread. Ann Surg $156: 114-124,1962$

2) 日本胆道外科研究会編：外科胆道癌取扱い規約. 東京, 金原出版, 1981

3）持永瑞恵, 田代征記, 石原信彦ほか：胆裹癌術後の 予後からみた治療法の検討一とくに組織学的深達 度とリンパ流を中心として一. 外科 $37: 952$ $-958,1975$

4) Pack GT, Miller TR, Brasfield RD: Total right hepatic lobectomy for cancer of the gallbladder : Report of three cases. Ann Surg 142 : 6-16, 1955

5）高崎 健, 小林誠一郎, 武藤晴臣注品：执大肝右葉 切除兼脞頭十二指腸切除により切除した胆囊癌 5 例の検討. 胆と腪 $1: 923-932,1980$

6) 角田 司, 土屋凉一, 吉野尞三：胆要癌の標準手術 術式. 消外 5:183-189, 1982

7）佐藤寿雄, 小山研二：胆重癌に対する払大根治手 術一いわゆる挔大胆摘術の遠隔成績からの反省か 5一。消外 5:191-197，1982

8）高田忠敬, 内山勝弘, 安田秀喜ほか：胆爱癌. 胆と 膵 $2: 813-820,1981$

9) Soupault $R$, Couimaud $C$ : Sur um procéeé nouveau de dérivation bilare intrahépatique: La cholangijejunostomie ganche sans sacritice hépatique. Presse Méd 65:1157-1159, 1957

10) Longmire WP, Sanford MC: Intrahepatic cholangiojejunostomy with partial hepatectomy for bkliary obstruction. Surgery $24: 264-276,1948$

11）水本龍二, 三田孝行：切除不能胆囊癌の治療. 消外 5: 199-204, 1982 